\title{
KUALITAS PELAYANAN PEMBUATAN NOMOR POKOK WAJIB PAJAK PRIBADI DI KANTOR PELAYANAN PAJAK PRATAMA JAYAPURA PROVINSI PAPUA
}

\author{
Dwi Arya Permana \\ Institut Agama Islam Negeri (IAIN) Fattahul Muluk Papua \\ E-mail: aryapermana2905@gmail.com \\ Sahudi \\ Institut Agama Islam Negeri (IAIN) Fattahul Muluk Papua \\ E-mail: sahudionline@gmail.com \\ Akbar Jaya \\ Institut Agama Islam Negeri (IAIN) Fattahul Muluk Papua \\ E-mail: akbar_jaya@yahoo.co.id
}

\begin{abstract}
One of the obligations of taxpayer is to enroll at Tax Service Office for getting NPWP (Taxpayer Identification Number). Having NPWP is an obligation for every taxpayer who has met the subjective and objective requirements based on the provisions of tax legislation. Taxpayers are obliged to make NPWP, while the government is obliged to give their rights as citizens to obtain public facilities in accordance with the desired expectations. For that, the government must have a commitment and provide services, especially in this case to taxpayers who will enroll the Taxpayer Identification Number in accordance with standards and applying the service quality benchmarks.

This research used a qualitative research. It used primary data (primary) and secondary data (supporting). The information from primary data sources in qualitative research was explored deeply through observation and interview techniques.

This research shows that the quality of services of Taxpayer Identification Number in Tax Service Office of Pratama Jayapura, Papua Province can be seen from the level of performance and the level of importance. The taxpayers think that the level of performance of the service officers in the manufacture of NPWP is very important and it has been in accordance with the service benchmarks of Tax Service Office of Pratama Jayapura. This office applies the principles in improving the quality of services. It includes leadership, education, planning, review, communication, and reward.
\end{abstract}

Keywords: Quality of Services, Enrolment of Personal NPWP 


\begin{abstract}
ABSTRAK
Pada umumnya salah satu kewajiban wajib pajak adalah mendaftarkan diri untuk memperoleh Nomor Pokok Wajib Pajak (NPWP) Pribadi. Kepemilikan NPWP Pribadi merupakan suatu kewajiban bagi setiap Wajib Pajak apabila telah memenuhi persyaratan subjektif dan objektif berdasarkan ketentuan peraturan perundang-undangan perpajakan. Wajib pajak wajib membuat NPWP Pribadi maka pemerintah berkewajiban untuk memberikan hak mereka sebagai warga negara untuk memperoleh fasilitas umum sesuai dengan harapan yang diinginkan, untuk itu pemerintah harus mempunyai komitmen dan memberikan pelayanan khususnya dalam hal ini kepada wajib pajak yang akan membuat Nomor Pokok Wajib Pajak Pribadi sesuai dengan standar dan menerapkan tolak ukur kualitas pelayanan.

Jenis penelitian yang digunakan adalah penelitian kualitatif. Penelitian ini menggunakan data primer (utama) dan sekunder (penunjang). Informasi dari sumber data primer dalam penelitian kualitatif pada umumnya dapat digali dengan lebih mendalam melalui teknik observasi dan wawancara.

Hasil penelitian dengan mengenai Kualitas Pelayanan Pembuatan Nomor Pokok Wajib Pajak (NPWP) Pribadi Pada Kantor Pelayanan Pajak Pratama Jayapura Provinsi Papua dapat dilihat mengenai Tingkat kinerja dan tingkat kepentingan. Wajib Pajak merasa tingkat kinerja pihak pelayanan pada bagian pembuatan NPWP sangat penting dan sudah sesuai dengan tolak ukur pelayanan Kantor Pelayan Pajak Pratama Jayapura Provinsi Papua. Kantor Pelayanan Pajak Pratama Jayapura Provinsi Papua dalam meningkatkan kualitas pelayanan dalam pembuatan Nomor Pokok Wajib Pajak (NPWP) Pribadi, Kantor Pelayanan Pajak Pratama Kota Jayapura Provinsi Papua Menerapkan prinsip dalam meningkatkan kualitas pelayanan Prinsip itu mencakup, Kepemimpinan, Pendidikan, Perencanaan, Ulasan (Review), Komunikasi, Penghargaan (Reward).
\end{abstract}

Kata Kunci: Kualitas Pelayanan, Pembuatan NPWP Pribadi.

\title{
PENDAHULUAN
}

Sitti Muliana, (2018:158) Peran serta kewajiban masyarakat dalam memenuhi kewajiban perpajakannya sangat diharapkan, dalam kenyataannya masih banyaknya wajib pajak yang tidak melaporkan besarnya pajak sesuai yang diberikan pemerintah dan lebih cenderung mengurangi biaya pajak yang telah ditetapkan. Pemungutan pajak memang bukan suatu yang mudah, selain peran serta pegawai pajak, kesadaran masyarakat juga dituntut untuk membayar pajak. Sistem pemungutan pajak di Indonesia telah mengalami perubahan dari official assessment system menjadi self assessment system sejak reformasi perpajakan pada tahun 1983.

Pada system ini masyarakat wajib diberi kepercayaan penuh dalam melaksanakan kewajiban perpajakan, untuk menghitung, memperhitungkan, membayar, dan melaporkan sendiri besarnya pajak yang harus dibayar. Sistem pemungutan pajak di Indonesia telah mengalami perubahan dari official assessment system menjadi self assessment system sejak reformasi perpajakan pada tahun 1983. Pada system ini masyarakat wajib diberi kepercayaan penuh dalam melaksanakan kewajiban perpajakan, untuk menghitung, memperhitungkan, membayar, dan melaporkan sendiri besarnya 
pajak yang harus dibayar. Supadmi menyatakan bahwa sistem self assessment menuntut adanya peran serta aktif dari masyarakat dalam pemenuhan kewajiban perpajakannya. Kesadaran dan kepatuhan yang tinggi dari wajib pajak merupakan faktor terpenting dari pelaksanaan sistem tersebut (Waluyo, 2008:7). Harahap berpendapat bahwa dianutnya system self assessment membawa misi dan konsekuensi perubahan sikap (kesadaran) warga masyarakat untuk membayar pajak secara sukarela (voluntary compliance). Kepatuhan memenuhi kewajiban perpajakan secara sukarela merupakan tulang punggung sistem self assessment. Secara umum, kewajiban perpajakan yang harus dipenuhi oleh wajib pajak berdasarkan sistem self assessment yaitu, Mendaftarkan diri untuk memperoleh Nomor Pokok Wajib Pajak (NPWP) Pribadi dan Membayar dan melaporkan pajak penghasilan dan pajak lainnya.

Salah satu kewajiban wajib pajak adalah mendaftarkan diri untuk memperoleh NPWP Pribadi. Kepemilikan NPWP Pribadi merupakan suatu kewajiban bagi setiap Wajib Pajak apabila telah memenuhi persyaratan subjektif dan objektif berdasarkan ketentuan peraturan perundang-undangan perpajakan. Selain karena kewajiban, kepemilikan NPWP juga dilatarbelakangi oleh berbagai manfaat wajib pajak atas NPWP Pribadi tersebut. Kebutuhan memiliki NPWP Pribadi bagi wajib pajak dapat diartikan sebagai suatu kondisi di mana wajib pajak tersebut sangat memerlukan NPWP Pribadi (Waluyo, 2008:3).

Wajib pajak wajib membuat NPWP Pribadi maka pemerintah berkewajiban untuk memberikan hak mereka sebagai warga negara untuk memperoleh fasilitas umum sesuai dengan harapan yang diinginkan, untuk itu pemerintah harus mempunyai komitmen dan memberikan pelayanan khususnya dalam hal ini kepada wajib pajak yang akan membuat nomor pokok wajib pajak sesuai dengan standar dan ketentuan yang telah ditetapkan. Begitupun sebaliknya, wajib pajak pun berkewajiban untuk membayar dan melapor pajak sesuai ketentuan yang berlaku dan bertanggungjawab atas perpajakkannya.

Aanastasia Devita, (2015:1) Dalam hal ini kualitas pelayanan sangat penting demi kenyamanan bagi setiap wajib pajak, khususnya yang ingin membuat nomor pokok wajib pajak. Pelayanan yang bersifat publik/umum. Berdasarkan organisasi yang menyelenggarakan, pelayanan publik/pelayanan umum dibagi menjadi dua, yaitu pelayanan umum dan pelayanan publik, pelayanan umum meliputi (1) pelayanan publik/pelayanan umum yang diselenggarakan oleh organisasi privat, (2) pelayanan publik/pelayanan umum yang diselenggarakan oleh kementrian yang dapat dibedakan menjadi dua, yaitu pelayana primer dan pelayanan sekunder.

Bersifat primer artinya semua penyediaan barang atau jasa publik yang diselenggarakan oleh pemerintah merupakan satu-satunya penyelenggara dan pengguna. Sedangkan yang bersifat sekunder artinya segala bentuk penyediaan barang dan jasa publik tentang kualitas pelayanan yang diberikan oleh Kantor Pajak Pratama.

Adapun tolak ukur kualitas pelayanan yang perlu diterapkan seperti dari segi fisik, komunikasi, keamanan, kesopanan, tanggungjawab, respon yang baik, pengarahan, konsistensi, serta kemampuan yang baik dalam pelayanan. Sama halnya 
dengan salah satu kementrian keuangan yakni Kantor Pajak Pratama Kota Jayapura Provinsi Papua, selain menggunakan tolak ukur 4S Juga memerlukan komitmen yang kuat dan serius untuk dapat menjalankan berbagai pemberian pelayanan mencangkup bidang perpajakan, salah satunya pelayanan pembuatan Nomor Pokok Wajib Pajak (NPWP) Pribadi.

Meski telah menerapkan tolak ukur kulaitas pelayanan akan tetapi masih terdapat kejadian yang ditemukan terkait kualitas pelayanan yaitu pada saat wajib pajak (WP) hendak membuat NPWP Pribadi. Dari pihak wajib pajak (WP) memberikan komplain atau protes terhadap pegawai dikarenakan komunikasi yang kurang dengan pihak wajib pajak (WP) yang menyebabkan pihak wajib pajak (WP) merasa belum paham betul mengenai NPWP Pribadi tersebut. Adapun pihak wajib pajak (WP) yang belum memahami dengan benar akan Nomor Pokok Wajib Pajak (NPWP) Pribadi sebab kurang diarahkannya pihak wajib pajak (WP) sehingga masih merasa kebingungan.

Dapat dilihat jelas bahwa kualitas pelayanan yang baik perlu diterapkan oleh pihak Kantor Pelayanan Pajak Pratama Jayapura Provinsi Papua agar dapat memberikan yang terbaik bagi pihak wajib pajak (WP) yaitu dengan menerapkan tolak ukur kualitas pelayanan dan juga harus memiliki cara untuk meningkatkan kualitas pelayanannya dalam hal ini pada Kantor Pelayanan Pajak pratama Jayapura Provinsi Papua, yaitu pada saat pembuatan Nomor pokok wajib pajak (NPWP) Pribadi. Untuk itu, penulis mengangkat judul "Kualitas Pelayanan Pembuatan Nomor Pokok Wajib Pajak (NPWP) di Kantor Pelayanan Pajak Pratama Jayapura Provinsi Papua”.

\section{KAJIAN LITERATUR}

\section{Kualitas Pelayanan}

Kualitas pelayanan menurut Chen dan Tan dalam Sebagaimana di kutip dalam penelitian I Putu Indra Pradnya Paramartha dan Ni Ketut Rasmini, (2010:648) adalah perbandingan antara apa yang diharapkan oleh pelanggan dengan apa yang diperolehnya. Menurut Supadmi, setelah melakukan penelitian menyatakan pelayanan yang berkualitas adalah suatu kepuasan kepada pelanggan dalam batas memenuhi standar pelayanan yang bisa dipertanggungjawabkan dengan cara terus-menerus. Adapun rasa puas atas pelayanan yang diberikan dalam meningkatkan kepatuhan wajib pajak dalam memenuhi kewajiban perpajakannya.

\section{Pelayanan}

Gronroos menjelaskan bahwa pelayanan adalah aktivitas atau serangkaian aktivitas yang bersifat tidak kasat mata (tidak dapat diraba) yang terjadi akibat adanya interaksi antara konsumen dan karyawan atau hal-hal lain yang disediakan oleh perusahaan pemberi pelayanan yang dimaksudkan untuk memecahkan permasalahan konsumen/pelanggan (Zaenal Mukarom dkk, 2015 :80). 
Berikut beberapa indikator yang termasuk ke dalam pelayanan:

1. Penyusunan Standar Pelayanan

Dengan dikeluarnya Undang-Undang Nomor 25 tahun 2009 tentang pelayanan publik diwajibkan untuk menyusun, menetapkan, dan menerapkan standar pelayanan. Hal ini dikuatkan dengan disahkannya Peraturan Menteri PANRB Nomor 36 tahun 2012 tentang Petunjuk Teknis Penyusunan, Penetapan dan Penerapan Standar Pelayanan sebagai peraturan pelaksana dari UU Nomor 25 tahun 2009 (Zaenal Mukarom dkk, 2015:115).

2. Tolak Ukur yang Dipergunakan sebagai Pedoman Penyelenggaraan Pelayanan Standar pelayanan adalah tolak ukur yang dipergunakan sebagai pedoman penyelenggaraan pelayanan dan acuan penilaian kualitas pelaya nan sebagai kewajiban dan janji penyelenggara kepada masyarakat dalam rangka pelayanan yang berkualitas, cepat, mudah, terjangkau, dan terukur. Tolak ukur pelayanan dapat dilihat menurut Zeithaml, Parasuraman dan Berry (1990), tolak ukur pelayanan ada sepuluh, yakni ketampakan fisik (tangibles), reliabilitas (reliability), responsivitas (responsiveness), kompetensi (competence), kesopanan (courtessy), kredibilitas (credibility), keamanan (assurance), akses (access), komunikasi (communication), dan pengertian (understanding) (Zaenal Mukarom dkk, 2015:116).

3. Prinsip-prinsip kualitas pelayanan menurut Wolkins, (Tjiptono, Fandi, 2004:17). untuk menciptakan suatu bentuk lingkungan yang baik bagi perusahaan untuk meningkatkan kualitas perusahaan harus mampu memenuhi enam prinsip utama yang berlaku bagi perusahaan. Enam prinsip pokok tersebut meliputi:

a. Kepemimpinan

Kualitas Perusahaan atau Kantor harus memiliki komitmen yang baik. Harus jiwa kepemimpinan untuk meningkatkan kinerja kualitas pelayanannya. Tanpa adanya jiwa kepemimpinan maka usaha untuk meningkatkan kualitas pelayanan hanya berdampak kecil terhadap Perusahaan atau Kantor.

b. Pendidikan

Semua personil perusahaan harus memperoleh pendidikan mengenai kualitas pelayanan. Aspek-aspek yang perlu mendapatkan pendidikan tersebut meliputi, pendidikan konsep kualitas sebagai strategi, alat dan teknik menjalankan strategi kualitas serta peranan dari peranan para pegawai dalam menjalankan kualitas pelayanan.

c. Perencanaan

Proses perencanaan harus mencakup pengukuran dan tujuan kualitas pelayanan yang dipergunakan dalam mengarahkan perusahaan untuk mencapai visinya.

d. Ulasan (Review)

Proses review merupakan hal yang paling efektif untuk mengubah perilaku organisasional. Proses ini merupakan suatu mekanisme yang menjamin adanya perhatian yang berlangsung secara terus-menerus untuk mencapai tujuan kualitas pelayanan. 
e. Komunikasi

Dalam menjalankan strategi kualitas pelayanan untuk meningkatkan kualitas pelayanan dipengaruhi oleh proses komunikasi yang baik dalam perusahaan.

f. Penghargaan dan pengakuan (total human reward)

Penghargaan dan pengakuan merupakan aspek yang penting dalam menjalankan kualitas pelayanan. Setiap pegawai yang berprestasi perlu diberi penghargaan dan prestasinya tersebut diakui. Dengan demikian dapat meningkatkan motivasi, moral kerja, rasa bangga, yang dapat memberikan kontribusi besar bagi perusahaan dan pihak yang dilayani.

\section{Wajib Pajak}

Siti Masruroh, (2013:23). Wajib Pajak adalah orang pribadi atau badan, meliputi pembayaran pajak, pemotongan pajak dan pemungutan pajak yang mempunyai hak dan kewajiban perpajakan sesuai dengan ketentuan peraturan Undang-Undang. Pengetahuan dan pemahaman akan peraturan perpajakan adalah proses dimana wajib pajak mengetahui tentang perpajakan dan mengaplikasikan pengetahuan itu untuk membayar pajak.

\section{NPWP}

NPWP adalah identitas atau tanda pengenal bagi Wajib Pajak yang diberikan Direktorat Jenderal Pajak (DJP). NPWP terdiri dari 15 digit angka sebagai kode unik. Kode unik inilah yang nantinya menjamin data perpajakan seseorang tidak tertukar dengan Wajib Pajak lainnya (https://klikpajak.id/blog/berita-pajak/5-hal-pentingseputar-npwp/,akses 27 Maret 2020).

\section{Kantor Pelayanan Pajak Pratama}

Sejak tahun 2002, secara bertahap KPP telah mengalami modernisasi sistem dan struktur organisasi menuju sebuah instansi yang berorientasi pada fungsi. Kemudian di tahun yang sama, dibentuklah dua KPP Wajib Pajak Besar atau yang dikenal juga sebagai LTO (Large Tax Office). KPP Pratama mulai terbentuk pada tahun 2006 hingga tahun 2008. KPP Pratama ini merupakan KPP terbanyak yang tersebar di seluruh wilayah Indonesia.

Tugas pokok KPP Pratama yaitu melaksanakan penyuluhan, pelayanan, dan pengawasan Wajib Pajak dalam bidang, Pajak Penghasilan $(\underline{\mathrm{PPh}})$, Pajak Pertambahan Nilai (PPN), Pajak penjualan atas Barang Mewah (PPnBM). Selain itu berfungsi sebagai pengumpulan, pencarian dan pengolahan data, pengamatan potensi perpajakan, penyajian informasi perpajakan, serta pendataan objek dan subjek pajak, sebagai penetapan dan penerbitan produk hukum perpajakan, Pengadministrasian dokumen dan berkas perpajakan, penerimaan dan pengolahan surat, pemberitahuan dan penerimaan surat lainnya, serta pelaksanaan ekstensifikasi, pengawasan kepatuhan kewajiban perpajakan Wajib Pajak. Pelaksanaan konsultasi perpajakan, pembetulan ketetapan pajak, dan pelaksanaan administrasi kantor (https://klikpajak.id/blog/beritapajak/ketahui-sejarah-tugas-fungsi-dan-struktur-kpp-pratama/, akses 27 Maret 2020). 


\section{METODE PENELITIAN}

Penelitian ini adalah penelitian kualitatif. Menurut Moleong Penelitiam kualitatif adalah penelitian yang bermaksud untuk memahami fenomena tentang apa yang dialami oleh subjek penelitian misalnya seperti perilaku, Presepsi, Motivasi, Tindakan dll. Secara Holistik dan dengan cara deskripsi dalam bentuk kata-kata dan bahasa, pada suatu konteks khusus yang alamiah dan dengan memanfaatkan berbagai metode alamiah (Enny Radjab dan Andi Jam'an, 2010:12). Lokasi penelitian dalam skripsi ini adalah di KPP Pratama Jayapura yang bertempat di Jalan Otonom No 3. Abepura-Jayapura, Depan Gedung Otonom, Jayapura.

Adapun kriteria dan informan yang berhubungan langsung dengan pihak KPP Pratama Jayapura Provinsi Papua yaitu, tiga orang wajib pajak dan satu pegawai KPP Pratama Jayapura Provinsi Papua dimana informan mengetahui mengenai Kualitas Pelayanan Khususnya Pembuatan Nomor Wajib Pajak Pribadi Di Kantor Pelayanan Pajak Pratama Jayapura Provinsi Papua.

Pengumpulan data dengan teknik observasi dan wawancara merupakan cara yang utama sekaligus sebagai penciri utama bagi penelitian kualitatif. Dalam hal ini wawancara ditujukan kepada Wajip Pajak yang mendapatkan pelayanan langsung dari KPP Pratama Jayapura Papua Provinsi Papua. Wawancara dilakukan dengan pertanyaan yang terus berkembang tetapi tetap fokus dan mengarah pada topik penelitian. Hasil observasi dan wawncara dari obyek penelitian akan didokumentasikan. Adapun Proses analisis data dalam penelitian kualitatif dimulai sejak merumuskan dan menjelaskan masalah (Syahrum dan Salim, 2015:144).

\section{HASIL DAN PEMBAHASAN}

\section{Hasil}

1. Tingkat kinerja dan tingkat kepentingan dalam Pelayanan Bagi Wajib Pajak Untuk Pembuatan Nomor Pokok Wajib Pajak (NPWP) Pribadi.

a. Tolak Ukur dari segi fisik, komunikasi, keamanan, serta tanggungjawab KPP Pratama Jayapura

Wawancara pribadi dengan pihak Wajib Pajak, Saudara Muh. Faiz Inai (2020 Maret 17) mengatakan dari segi fisiknya seperti tidak adanya kecacatan dari pegawainya dibagian pelayanan pembuatan Nomor Pokok Wajib Pajak (NPWP) Pribadi. Adapun dari segi kesopanannya juga untuk pegawai yang dibagian pembuatan Nomor Pokok Wajib Pajak (NPWP) Pribadi sangat baik, itu yang membuat Wajib Pajak senang dikarenakan pegawai yang dibagian Pembuatan Nomor Pokok Wajib Pajak (NPWP) Pribadi sangat ramah terhadap Wajib Pajak. Sedangkan dari segi keamanannya dari pihak pegawai pelayanan dalam pembuatan Nomor Pokok Wajib Pajak (NPWP) Pribadi mereka sangat menjamin keamanan data setiap Wajib Pajak yang ingin membuat Nomor Pokok Wajib Pajak (NPWP) Pribadi. 
Segi komunikasinya pihak pegawai pada bagian pelayanan dalam pembuatan Nomor Pokok Wajib Pajak (NPWP) Pribadi terhadap Wajib Pajak sangat baik dalam berkomunikasi untuk membuat Nomor Pokok Wajib Pajak (NPWP) Pribadi karena komunikasi yang sangat baik itu penting dalam bagian pelayanan apalagi dalam pembuatan Nomor Pokok Wajib Pajak (NPWP) Pribadi, dan dari segi tanggungjawab pihak pegawai pada bagian pembuatan Nomor Pokok Wajib Pajak (NPWP) Pribadi mereka sangat bertanggungjawab dalam menjaga data pribadi pihak Wajib Pajak yang akan membuat Nomor Pokok Wajib Pajak (NPWP) Pribadi, hal ini sangat penting demi memberikan pelayanan yang baik terhadap Wajib Pajak.

b. Tolak Ukur berdasarkan respon yang diberikan pihak pelayanan kepada Wajib Pajak

Wawancara pribadi dengan pihak Wajib Pajak, Saudara Agung Wicaksono (2020 Maret 17) mengatakan respon yang diberikan oleh pihak pelayanan bagian pembuatan Nomor Pokok Wajib Pajak (NPWP) Pribadi kepada Wajib Pajak yang hendak membuat Nomor Pokok Wajib Pajak (NPWP) Pribadi sangat baik. Selain itu juga, pihak Wajib Pajak menyebutkan bahwa respon yang baik itu sangat penting. karena dengan adanya respon baik dari pegawai pada bagian pembuatan Nomor Pokok Wajib Pajak (NPWP) Pribadi terhadap Wajib Pajak yang ingin membuat Nomor Pokok Wajib Pajak (NPWP) Pribadi. sehingga memudahkan pihak Wajib Pajak dalam mendapatkan Nomor Pokok Wajib Pajak (NPWP) Pribadi.

c. Tolak Ukur berdasarkan arahan pihak pelayanan pembuatan NPWP

Wawancara pribadi dengan pihak Wajib Pajak, Saudara Agung Wicaksono (2020 Maret 17) mengatakan pihak Wajib Pajak mendapatkan pengarahan dengan baik dari pihak pelayanan pada Kantor Pelayanan Pajak Pratama Jayapura Provinsi Papua. Selain itu juga Wajib Pajak menyatakan bahwa arahan yang baik itu sangat penting agar pihak Wajib Pajak tidak merasa kebingungan dan kewalahan.

Arahan yang dimaksud oleh pihak Wajib Pajak pada Kantor Pelayanan Pajak Pratama Jayapura Provinsi Papua yaitu meliputi mulai dari pihak Wajib Pajak datang menyatakan keinginannya untuk membuat Nomor Pokok Wajib Pajak (NPWP) Pribadi, kemudian pihak pegawai bagian pelayanan memberikan arahan untuk mengisi formulir yang diberikan kepada pihak Wajib Pajak, selanjutnya Wajib Pajak akan di arahkan untuk mengantri yang akan dipanggil sesuai dengan nomor urut antrian untuk mendapatkan Nomor Pokok Wajib Pajak (NPWP) Pribadi.

d. Tolak Ukur berdasarkan konsistensi pihak pelayanan bagian pembuatan NPWP

Wawancara pribadi dengan pihak Wajib Pajak, Saudara Moch. Andriana Gantina (2020 Maret 21) mengatakan saat pihak Wajib Pajak hendak datang kemudian menyatakan keinginannya untuk membuat Nomor Pokok Wajib Pajak (NPWP) Pribadi. Setelah itu pihak pegawai pada bagian pelayanan pada Kantor 
Pelayanan Pajak Pratama Jayapura Provinsi Papua segera melayani pihak Wajib Pajak tersebut sesuai dengan prosedur dan sesuai dengan langkah-langkah yang telah ditetapkan pada saat pihak Wajib Pajak yang hendak membuat Nomor Pokok Wajib Pajak (NPWP) Pribadi sehingga berjalan sesuai dengan keinginan pihak Wajib Pajak.

e. Tolak Ukur berdasarkan kemampuan yang baik dalam pelayanan di Kantor KPP Pratama Jayapura Provinsi Papua

Wawancara pribadi dengan pihak Wajib Pajak, Saudara Moch. Andriana Gantina (2020 Maret 21) mengatakan Wajib Pajak merasa dilayani dengan baik oleh pihak pelayanan pada Kantor Pelayanan Pajak Pratama Jayapura Provinsi Papua selain itu Wajib Pajak merasa hal itu sangat penting dalam pelayanan yang baik dikarenakan itu bisa menjadi nilai tambah/nilai positif untuk pegawainya dibagian pelayanan. Hal ini dapat dibuktikan dengan cara pihak pegawai bagian pelayanan pembuatan Nomor Pokok Wajib Pajak (NPWP) Pribadi melayani pihak Wajib Pajak sesuai dengan prosedur yang berlaku di Kantor Pelayanan Pajak Pratama Jayapura Provinsi Papua dan keinginan Wajib Pajak.

2. Apa yang dilakukan Kantor Pelayanan Pajak Pratama Pajak Pratama Kota Jayapura Provinsi Papua dalam meningkatkan kualitas pelayanan pada bagian pembuatan Nomor Pokok Wajib Pajak (NPWP) Pribadi.

a. Prinsip Kepemimpinan

Wawancara pribadi dengan pihak Pegawai Pajak, Bapak Hilmi (2020 Maret 20) mengatakan Sifat kepemimpinan harus dimiliki agar dapat mengarahkan wajib pajak sesuai dengan kebutuhan wajib pajak. Jiwa kepemimpinan tidak harus ada pada bagian atasannya saja, melainkan pada diri setiap individu termasuk pada pihak pegawai yang tugasnya melayani para Wajib Pajak yang akan membuat Nomor Pokok Wajib Pajak (NPWP) Pribadi. Pihak Pegawai bagian pelayanan harus memiliki jiwa kepemimpinan, yang tugasnya mengarahkan pihak Wajib Pajak agar paham mengenai pembuatan Nomor Pokok Wajib Pajak (NPWP) Pribadi yaitu dimulai dari pengisian formulir hingga pihak Wajib Pajak mendapatkan Nomor Pokok Wajib Pajak (NPWP) Pribadinya.

b. Prinsip pendidikan

Wawancara pribadi dengan pihak Pegawai Pajak, Bapak Hilmi (2020 Maret 20) mengatakan pendidikan juga merupakan poin yang penting bagi pihak pelayana dikarenakan pada bagian pelayanan secara langsung berinterkasi dengan pihak Wajib Pajak. Pihak Pegawai bagian pelayanan harus dibekali dengan pengetahuan yang baik mengenai bagaimana harus melayani pihak Wajib Pajak yang hendak membuat Nomor Pokok Wajib Pajak (NPWP) Pribadi dengan baik serta sesuai dengan kebutuhan para si Wajib Pajak agar setelah mendapatkan Nomor Pokok Wajib Pajak (NPWP) Pribadi, pihak Wajib Pajak menjadi paham terkait kegunaan dari Nomor Pokok Wajib Pajak (NPWP) Pribadi milik mereka.

c. Prinsip Perencanaan 
Wawancara pribadi dengan pihak Pegawai Pajak, Bapak Hilmi (2020 Maret 20) mengatakan perencanaan diperlukan untuk mencapai visi dan misi pada Kantor Pelayanan Pajak Pratama Jayapura Provinsi Papua dengan membuat perencanaan yang baik dalam melayani pihak Wajib Pajak yang hendak membuat Nomor Pokok Wajib Pajak (NPWP) Pribadi serta memberikan pengertian mengenai pentingnya pembuatan Nomor Pokok Wajib Pajak (NPWP) sehingga timbul kesadaran akan pentingnya pajak serta membayar pajak.

d. Prinsip Ulasan (Review)

Wawancara pribadi dengan pihak Pegawai Pajak, Bapak Hilmi (2020 Maret 20) mengatakan review dilakukan untuk melihat kinerja dari pihak pelayanan apakah ada yang perlu dibenahi ataukah sudah baik. Jika ada yang perlu dibenahi, maka akan dibenahi sehingga dapat terus meningkatkan kualitas dalam pelayanan dalam hal ini pelayanan pada saat melayani pihak Wajib Pajak yang hendak membuat Nomor Pokok Wajib Pajak (NPWP) Pribadi. Dengan begitu tidak akan terjadi complain oleh pihak Wajib Pajak terhadap pihak pelayanan pada Kantor Pelayanan Pajak Pratama Jayapura Provinsi Papua

e. Prinsip Komunikasi

Wawancara pribadi dengan pihak Pegawai Pajak, Bapak Hilmi (2020 Maret 20) mengatakan komunikasi yang baik sangat diperlukan karena dengan adanya komunikasi yang baik, akan membuat pihak Wajib Pajak nyaman berkomunikasi dengan pihak pelayanan pada saat akan membuat Nomor Pokok Wajib Pajak (NPWP) Pribadi karena mereka diarahkan dengan baik sehingga paham akan pentingnya Nomor Pokok Wajib Pajak (NPWP) Pribadi yang akan mereka miliki dan juga paham akan pentingnya membayar pajak setelah memiliki Nomor Pokok Wajib Pajak (NPWP) Pribadi.

f. Prinsip Penghargaan atau Reward

Penghargaan atau reward bertujuan untuk diberikan kepada pegawai agar pihak pelayanan semakin termotivasi lagi serta semangat dalam melayani wajib pajak, agar dapat terus meningkatkan kualitas pelayanannya kepada pihak Wajib Pajak. Meskipun kemungkinan akan timbul komplain, pihak Kantor Pajak Pratama Jayapura Provinsi Papua telah menyiapkan prinsip untuk meningkatkan kualitas pelayanan agar tidak ada lagi komplain dari pihak Wajib Pajak (WP) terkait tolak ukur yang ada di Kantor Pajak Pratama Jayapura Provinsi Papua.

\section{Pembahasan}

1. Tingkat kinerja dan tingkat kepentingan dalam Pelayanan Bagi Wajib Pajak Untuk Pembuatan Nomor Pokok Wajib Pajak (NPWP)

Berdasarkan hasil penelitian di atas dalam melihat tingkat kinerja dan tingkat kepentingan pelayanan bagi Wajib Pajak dalam pembuatan NPWP harus berdasar pada tolak ukur pelayanan Kantor KPP Pratama Jayapura yaitu tolak ukur dilihat dari segi fisik, komunikasi, keamanan, kesopanan, tanggungjawab, respon yang baik, pengarahan, konsistensi, serta kemampuan yang baik dalam pelayanan. 
Wajib Pajak merasa tingkat kinerja pihak pelayanan pada bagian pembuatan NPWP sudah sesuai dengan tolak ukur pelayanan Kantor KPP Pratama Jayapura.

Hal ini sesuai dengan teori yang dikemukakan oleh Zeithaml, Parasuraman dan Berry:

"Tolak ukur pelayanan ada sepuluh, yakni ketampakan fisik (tangibles), reliabilitas (reliability), responsivitas (responsiveness), kompetensi (competence), kesopanan (courtessy), kredibilitas (credibility), keamanan (assurance), akses (access), komunikasi (communication), dan pengertian (understanding).

Dari hasil penelitian dan landasan teori dapat dilihat bahwa terdapat kecocokan antara keduanya yaitu secara fisik, kesopanan, keamanan, komunikasi, bertanggung jawab, dan dapat dipercaya membuat Wajib Pajak merasa pihak pelayanan sudah sangat baik dalam memberikan pelayanannya dapat dibuktikan dari segi fisiknya seperti tidak adanya kecacatan dari pegawainya dibagian pelayanan pembuatan Nomor Pokok Wajib Pajak (NPWP) Pribadi, adapun dari segi kesopanannya juga untuk pegawai yang dibagian pembuatan Nomor Pokok Wajib Pajak (NPWP) Pribadi sangat baik, itu yang membuat Wajib Pajak senang dikarenakan pegawai yang dibagian Pembuatan Nomor Pokok Wajib Pajak (NPWP) Pribadi sangat ramah terhadap Wajib Pajak.

Dari segi keamanannya dari pihak pegawai pelayanan dalam pembuatan Nomor Pokok Wajib Pajak (NPWP) Pribadi mereka sangat menjamin keamanan data setiap Wajib Pajak yang ingin membuat Nomor Pokok Wajib Pajak (NPWP) Pribadi, ada juga dari segi komunikasinya pihak pegawai pada bagian pelayanan dalam pembuatan Nomor Pokok Wajib Pajak (NPWP) Pribadi terhadap Wajib Pajak sangat baik dalam berkomunikasi untuk membuat Nomor Pokok Wajib Pajak (NPWP) Pribadi karena komunikasi yang sangat baik itu penting dalam bagian pelayanan apalagi dalam pembuatan Nomor Pokok Wajib Pajak (NPWP) Pribadi.

Dari segi tanggungjawab pihak pegawai pada bagian pembuatan Nomor Pokok Wajib Pajak (NPWP) Pribadi mereka sangat bertanggungjawab dalam menjaga data pribadi pihak Wajib Pajak yang akan membuat Nomor Pokok Wajib Pajak (NPWP) Pribadi, hal ini sangat penting demi memberikan pelayanan yang baik terhadap Wajib Pajak. Selain itu respon yang diberikan oleh pihak pelayanan bagian pembuatan Nomor Pokok Wajib Pajak (NPWP) Pribadi kepada Pihak Wajib Pajak yang hendak membuat Nomor Pokok Wajib Pajak (NPWP) Pribadi sangat baik. Pihak Wajib Pajak menyebutkan bahwa respon yang baik itu sangat penting. karena dengan adanya respon baik dari pegawai pada bagian pembuatan Nomor Pokok Wajib Pajak (NPWP) Pribadi terhadap Wajib Pajak yang ingin membuat Nomor Pokok Wajib Pajak (NPWP) Pribadi. sehingga memudahkan pihak Wajib Pajak dalam mendapatkan Nomor Pokok Wajib Pajak (NPWP) Pribadi.

Pihak Wajib Pajak juga mendapatkan pengarahan dengan baik dari pihak pelayanan pada Kantor Pelayanan Pajak Pratama Jayapura Provinsi Papua. Selain itu juga Wajib Pajak menyatakan bahwa arahan yang baik itu sangat penting agar pihak Wajib Pajak tidak merasa kebingungan dan kewalahan. Arahan yang dimaksud oleh 
pihak Wajib Pajak pada Kantor Pelayanan Pajak Pratama Jayapura Provinsi Papua yaitu meliputi mulai dari pihak Wajib Pajak datang menyatakan keinginannya untuk membuat Nomor Pokok Wajib Pajak (NPWP) Pribadi.

Pihak pegawai bagian pelayanan memberikan arahan untuk mengisi formulir yang diberikan kepada pihak Wajib Pajak adapun jika pihak Wajib Pajak belum paham dengan formulir yang harus di isi untuk pembuatan Nomor Pokok Wajib Pajak (NPWP) Pribadi maka pihak pegawai bagian pelayanan harus menjelaskan secara detail dalam pengisian formulir. Setelah formulir diisi dengan lengkap dan persyaratan dalam pembuatan Nomor Pokok Wajib Pajak (NPWP) Pribadi juga sudah lengkap maka dari pihak pegawai bagian pelayanan untuk Wajib Pajak akan di arahkan untuk mengantri yang akan dipanggil sesuai dengan nomor urut antrian untuk mendapatkan Nomor Pokok Wajib Pajak (NPWP) Pribadi.

Pihak Wajib Pajak menyatakan pelayanan pada bagian pembuatan Nomor Pokok Wajib Pajak (NPWP) Pribadi sudah baik. Selain itu juga mereka (Wajib Pajak) merasa kosistensi dalam melayani Wajib Pajak itu merupakan hal yang sangat penting. Karena hal ini terlihat pada saat pihak Wajib Pajak hendak datang kemudian menyatakan keinginannya untuk membuat Nomor Pokok Wajib Pajak (NPWP) Pribadi, kemudian pihak pegawai pada bagian pelayanan pada Kantor Pelayanan Pajak Pratama Jayapura Provinsi Papua segera melayani pihak Wajib Pajak tersebut sesuai dengan prosedur dan sesuai dengan langkah-langkah yang telah ditetapkan pada saat pihak Wajib Pajak yang hendak membuat Nomor Pokok Wajib Pajak (NPWP) Pribadi sehingga berjalan sesuai dengan keinginan pihak Wajib Pajak.

Wajib Pajak merasa dilayani dengan baik oleh pihak pelayanan pada Kantor Pelayanan Pajak Pratama Jayapura Provinsi Papua selain itu Wajib Pajak merasa hal itu sangat penting dikarenakan bisa menjadi nilai tambah/nilai positif untuk pegawainya dibagian pelayanan. Hal ini dapat dibuktikan dengan cara pihak pegawai bagian pelayanan pembuatan Nomor Pokok Wajib Pajak (NPWP) Pribadi, telah melayani pihak Wajib Pajak sesuai dengan prosedur yang berlaku di Kantor Pelayanan Pajak Pratama Jayapura Provinsi Papua dan keinginan Wajib Pajak.

2. Apa yang dilakukan Kantor Pelayanan Pajak Pratama Kota Jayapura Provinsi Papua dalam meningkatkan kualitas pelayanan pada bagian pembuatan Nomor Pokok Wajib Pajak (NPWP)

Berdasarkan hasil penelitian di atas dalam meningkatkan kualitas pelayanan di Kantor Pelayanan Pajak Pratama Kota Jayapura Provinsi Papua, diterapkan prinsip dalam meningkatkan kualitas pelayanan. Prinsip itu mencakup, Kepemimpinan, Pendidikan, Perencanaan, Ulasan (Review), Komunikasi, Penghargaan (Reward).

Hal ini sesuai dengan teori yang dikemukakan oleh Wolkins:

"Untuk menciptakan suatu bentuk lingkungan yang baik bagi perusahaan untuk meningkatkan kualitas perusahaan harus mampu memenuhi enam prinsip utama yang berlaku bagi perusahaan. Enam prinsip pokok tersebut meliputi, 
Kepemimpinan, Pendidikan, Perencanaan, Review, Komunikasi, Penghargaan dan Pengakuan (Reward)."

Dari hasil penelitian dan landasan teori dapat dilihat bahwa terdapat kecocokan antara keduanya yaitu pihak Kantor KPP Pratama menggunakan teori yang dikemukakan oleh Wolkin dalam meningkatkan kualitas pelayanan yaitu berdasarkan enam prinsip meliputi, kepemimpinan, pendidikan, perencanaan, review, komunikasi, serta penghargaan dan pengakuan (reward).

Hal ini dapat dijabarkan yaitu pertama, Pihak Pegawai bagian pelayanan harus memiliki jiwa kepemimpinan, yang tugasnya mengarahkan pihak Wajib Pajak agar paham mengenai pembuatan Nomor Pokok Wajib Pajak (NPWP) Pribadi yaitu dimulai dari pengisian formulir hingga pihak Wajib Pajak mendapatkan Nomor Pokok Wajib Pajak (NPWP) Pribadinya. Hal ini sesuai dengan teori Wolkins yang menyatakan bahwa, Kualitas perusahaan atau Kantor harus memiliki komitmen yang baik. Harus memiliki jiwa kepemimpinan untuk meningkatkan kinerja kualitas pelayanannya. Tanpa adanya jiwa kepemimpinan maka usaha untuk meningkatkan kualitas pelayanan hanya berdampak kecil terhadap perusahaan atau Kantor.

Kedua, pendidikan juga merupakan poin yang sangat penting bagi pegawai/pihak bagian pelayanan di Kantor Pelayanan Pajak Pratama Jayapura Provinsi Papua dikarenakan pada bagian pelayanan pegawainya secara langsung berinterkasi ataupun bertatap muka dengan pihak Wajib Pajak, sehingga pegawai bagian pelayanan harus dibekali dengan pengetahuan yang baik mengenai bagaimana pegawainya harus melayani pihak Wajib Pajak yang hendak membuat Nomor Pokok Wajib Pajak (NPWP) Pribadi dengan baik serta sesuai dengan kebutuhan para Wajib Pajak agar setelah mendapatkan Nomor Pokok Wajib Pajak (NPWP) Pribadi, sehingga pihak Wajib Pajak menjadi paham terkait kegunaan dari Nomor Pokok Wajib Pajak (NPWP) Pribadi milik mereka.

Dari teori yang dikemukakan oleh Wolkins bahwasannya jenjang pendidikan itu sangat penting apalagi untuk Kantor Pelayanan Pajak Pratama Jayapura Porvinsi Papua, karena pengetahuan dan softskiil harus diterapkan agar pegawai yang ada di Kantor Pelayanan Pajak Pratama Jayapura Provinsi Papua khususnya dibagian pelayanan yang membantu Wajib Pajak (WP) dalam membuat Nomor Pokok Wajib Pajak (NPWP) Pribadi itu paham dalam pembuatan NPWP Pribadi.

Ketiga, perencanaan diperlukan untuk mencapai visi dan misi pada Kantor Pelayanan Pajak Pratama Jayapura Provinsi Papua dengan membuat perencanaan yang baik dalam melayani pihak Wajib Pajak yang hendak membuat Nomor Pokok Wajib Pajak (NPWP) Pribadi serta memberikan pengertian mengenai pentingnya pembuatan Nomor Pokok Wajib Pajak (NPWP) Pribadi sehingga timbul kesadaran akan pentingnya pajak serta membayar pajak. Dengan adanya perencanaan yang baik pada Kantor Pelayanan Pajak Pratama Jayapura Provinsi Papua 
Hal ini sesuai dengan teori Wolkins yang menyatakan bahwa Proses perencanaan harus mencakup pengukuran dan tujuan kualitas pelayanan yang dipergunakan dalam mengarahkan perusahaan untuk mencapai visinya.

Keempat, review dilakukan untuk melihat kinerja dari pihak pelayanan apakah ada yang perlu dibenahi ataukah sudah baik. Jika ada yang perlu dibenahi, maka akan dibenahi sehingga dapat terus meningkatkan kualitas dalam pelayanan dalam hal ini pelayanan pada saat melayani pihak Wajib Pajak yang hendak membuat Nomor Pokok Wajib Pajak (NPWP) Pribadi. Dengan begitu tidak akan terjadi komplain oleh pihak Wajib Pajak terhadap pihak pelayanan pada Kantor Pelayanan Pajak Pratama Jayapura Provinsi Papua.

Hal ini sesuai dengan teori Wolkins yang menyatakan bahwa, Proses review merupakan hal yang paling efektif untuk mengubah perilaku organisasional. Proses ini merupakan suatu mekanisme yang menjamin adanya perhatian yang berlangsung secara terus-menerus untuk mencapai tujuan kualitas pelayanan.

Kelima, Komunikasi yang baik akan membuat pihak Wajib Pajak nyaman berkomunikasi dengan pihak pelayanan pada saat akan membuat Nomor Pokok Wajib Pajak (NPWP) Pribadi karena mereka diarahkan dengan baik sehingga paham akan pentingnya Nomor Pokok Wajib Pajak (NPWP) Pribadi yang akan mereka miliki dan juga paham akan pentingnya membayar pajak setelah memiliki Nomor Pokok Wajib Pajak (NPWP) Pribadi.

Hal ini sesuai dengan teori Wolkins yang menyatakan bahwa, Dalam menjalankan strategi kualitas pelayanan untuk meningkatkan kualitas pelayanan dipengaruhi oleh proses komunikasi yang baik dalam perusahaan.

Keenam, penghargaan atau reward bertujuan untuk diberikan kepada pegawai khususnya di pihak pelayanan semakin termotivasi lagi serta semangat dalam melayani Wajib Pajak (WP), agar dapat terus meningkatkan kualitas pelayanannya kepada pihak Wajib Pajak (WP) penghargaan yang diberikan secara langsung dari Kantor Pelayanan Pajak Pratama Jayapura Provinsi Papua seperti hadiah ataupun jabatannya bisa dinaikkan. Hal ini sesuai dengan teori Wolkins yang menyatakan bahwa, Penghargaan dan pengakuan merupakan aspek yang penting dalam menjalankan kualitas pelayanan. Setiap pegawai yang berprestasi perlu diberi penghargaan dan prestasinya tersebut diakui. Dengan demikian dapat meningkatkan motivasi, moral kerja, rasa bangga, yang dapat memberikan kontribusi besar bagi perusahaan dan pihak yang dilayani.

\section{KESIMPULAN DAN SARAN \\ Kesimpulan}

1. Tingkat kinerja dan tingkat kepentingan, Wajib Pajak merasa tingkat kinerja pihak pelayanan pada bagian pembuatan NPWP sangat penting dan sudah sesuai dengan tolak ukur pelayanan Kantor KPP Pratama Jayapura baik itu dari segi fisik, kesopanan, keamanan, komunikasi, bertanggungjawab dan dapat dipercaya, respon yang baik, diarahkan dengan baik, serta konsisten dalam bekerja. 
2. Dalam meningkatkan kualitas pelayanan dalam pembuatan NPWP, Kantor Pelayanan Pajak Pratama Kota Jayapura Provinsi Papua Menerapkan prinsip dalam meningkatkan kualitas pelayanan. Prinsip itu mencakup, Kepemimpinan, Pendidikan, Perencanaan, Ulasan (Review), Komunikasi, Penghargaan (Reward).

\section{Saran}

Berkenaan dengan pembahasan dan kesimpulan di atas, maka penulis memberikan saran sebagai berikut:

1. Bagi Pihak Lembaga

Pihak Kantor KPP Pratama Jayapura berdasarkan tingkat kinerja dan tingkat kepentingan dalam pelayanan pembuatan NPWP Pribadi, dimana berdasarkan pernyataan dari para informan yaitu Wajib Pajak bahwa Pihak Kantor KPP Pratama sudah menggunakan tolak ukur sesuai dengan yang ditetapkan. Hal ini patut dipertahankan karena para Wajib Pajak mengatakan bahwa tolak ukur tersebut sangatlah penting. Selain itu untuk meningkatkan kualitas pelayanan, pihak Kantor KPP Pratama harus tetap menerapkan prinsip sesuai dengan yang telah ditetapkan demi kenyamanan para Wajib Pajak agar tidak ada Wajib pajak yang complain karena merasa kebingungan tentang pembuatan NPWP Pribadi.

2. Bagi Pihak Wajib Pajak

Pihak Wajib Pajak haruslah mematuhi standar layanan umum yang telah ditetapkan oleh Pihak Kantor KPP Pratama Jayapura terutama standar layanan umum dalam pembuatan NPWP Pribadi.

3. Bagi Peneliti Selanjutnya

Bagi peneliti selanjutnya dapat dimanfaatkan sebagai bahan rujukan dalam melakukan penelitian yang berkaitan dengan Kualitas Pelayanan Dalam Pembuatan NPWP Pada Kantor KPP Pratama Jayapura Provinsi Papua.

\section{DAFTAR REFERENSI}

Masruroh Siti, (2013), "Pengaruh Kemanfaatan NPWP, "Pemahaman Wajib Pajak, Kualitas Pelayanan, dan Sanksi Perpajakan Terhadap Kepatuhan Wajib Pajak (Studi Empiris WP OP di Kabupaten Tegal)”, Skripsi S1 Fakultas Ekonomika dan Bisnis, Universitas Diponegoro.

Manossoh Devita Anastasia, (2013), Tulusan Femmy M.G. dan Londa Y. Very,

"Kualitas Pelayanan Pembuatan Nomor Pokok Wajib Pajak Di Kantor Pelayanan Pajak Pratama Manado”.

Paramartha Pradnya Indra Putu I, Rasmini Ni Ketut, (2016), "Pengaruh Kualitas Pelayanan, Pengetahuan dan Sanksi Perpajakan Pada Kepatuhan Wajib Pajak Badan E-Jurnal Akutansi Univesitas Udayana”, Vol. 15, No.1.

Fandy,Tjiptono, (2004), “Manajemen Jasa, Edisi Pertama”, Andi Offset, (Yogyakarta) Mukarom Zaenal dan Laksana Muhibudin Wijaya, (2015), "Manajemen Pelayanan Publik”. 
Radjab Enny dan Jam'an Andi, (2010), “Metodologi Penelitian Bisnis”, Lembaga (Makassar: Universitas Muhammadiyah Makassar, Februari).

Waluyo, (2000), "Perubahan UU Perpajakan Era Reformasi", Salemba Empat (Jakarta).

Mamat Faiz Inai, (2020 Maret 17), Wawancara Pribadi

Agung Wicaksono, (2020 Maret 17), Wawancara Pribadi

Hilmi, (2020 Maret 20), Wawancara Pribadi

Moch. Andriana Gantina, (2020 Maret 21), Wawancara Pribadi

Https://klikpajak.id/blog/bayar-pajak/cara-membuat-npwp-elektronik/ diakses pada 27 Maret 2020

Https://klikpajak.id/blog/berita-pajak/ketahui-sejarah-tugas-fungsi-dan-struktur-kpppratama, diakses pada 27 Maret 2020 